\title{
Policy analysis for tropical marine reserves: challenges and directions
}

\author{
Murray A. Rudd \\ Mansholt Graduate School, Wageningen University. Hollandseweg 1, 6706 KN Wageningen, The Netherlands
}

Mark H. Tupper

University of Guam Marine Laboratory, UOG Station, Mangilao, Guam 96923

Henk Folmer

Mansholt Graduate School, Wageningen University. Hollandseweg 1, 6706 KN Wageningen, The Netherlands

and

G. C. van Kooten

Department of Economics, University of Victoria, PO Box 1700 STN CSC, Victoria, BC, Canada V8W $2 Y 2$

Current Contact Information:

Murray A. Rudd

Fisheries and Oceans Canada, Maritimes Region

Policy and Economics Branch

PO Box 1035, 176 Portland Street

Dartmouth, Nova Scotia

Canada B2Y 4T3

Phone: 902-426-4825

Fax: 902-426-6767

Email: RuddM@dfo-mpo.gc.ca

Suggested Running Title: Policy Analysis for Marine Reserves 


\section{$\underline{\text { Abstract }}$}

Marine reserves are considered to be a central tool for marine ecosystem-based management in tropical inshore fisheries. The arguments supporting marine reserves are often based on both the nonmarket values of ecological amenities marine reserves provide and the pragmatic cost saving advantages relating to reserve monitoring and enforcement. Marine reserves are, however, only one of a suite of possible policy options that might be used to achieve conservation and fisheries management objectives and have rarely been the focus of rigorous policy analyses that consider a full range of economic costs and benefits, including the transaction costs of management. If credible analyses are not undertaken, there is a danger that current enthusiasm for marine reserves may wane as economic performance fails to meet presumed potential. Fully accounting for the value of ecological services flowing from marine reserves requires consideration of increased size and abundance of focal species within reserve boundaries, emigration of target species from reserves to adjacent fishing grounds, changes in ecological resilience, and behavioral responses of fishers to spatially explicit closures. Expanding policy assessments beyond standard cost-benefit analysis also requires considering the impact of social capital on the costs of managing fisheries. In the short term, the amount of social capital that communities possess and the capacity of the State to support the rights of individuals and communities will affect the relative efficiency of marine reserves. Reserves may be the most efficient policy option when both Community and State capacity is high, but may not be when one and/or the other is weak. In the longer term, the level of social capital that a society possesses and the level of uncertainty in ecological and social systems will also impact the appropriate level of devolution or decentralization of fisheries governance. Determining the proper balance of the 'State' and the 'Community' in tropical fisheries governance will require broad comparative studies of marine reserves and alternative policy tools. 
Keywords: comanagement; cost-benefit analysis; institutional analysis; marine reserves; nonmarket valuation; social capital

\title{
Contents
}

\author{
ABSTRACT \\ CONTENTS \\ INTRODUCTION
}

\section{ECOLOGICAL SERVICES AND THE VALUE OF MARINE RESERVES}

INCREASED SIZE AND ABUNDANCE WITHIN MARINE RESERVES

SPILlOVER FROM MARINE RESERVES TO ADJACENT COMMERCIAL FISHING GROUNDS

INCREASED ECOLOGICAL RESILIENCE DUE TO MARINE RESERVES

Trophic Effects

Effects of Connectivity

\section{TRANSACTION COSTS AND MARINE RESERVE POLICY ANALYSIS}

THEORETICAL BACKGROUND

Common Pool Resources and Common Property

Transaction Cost Economics

Strategies, Norms and Rules

Institutions

Social Capital

COMPARATIVE POLICY ANALYSIS OF MARINE RESERVES

Social Capital and Fisheries Management - Three Cases

The Importance of Social Capital in Analyses of Marine Reserves

Causal Complexity in Comparative Analyses of Marine Reserves

ECONOMICALly EFFICIENT FISHERIES GOVERNANCE REGIMES

The Proper Scope of Governance

Impacts of Uncertainty on Transaction Costs and Governance

\section{CONCLUDING REMARKS}

ACKNOWLEDGEMENTS

\section{LITERATURE CITED}




\section{Introduction}

Despite the long-term importance of marine ecological goods and services to humans, it is evident that efforts to govern fisheries have often failed (Botsford et al. 1997; NRC 1999; FAO 2000). Commercially important species under increasing fishing pressure are being depleted (FAO 2000), resource rents are dissipated under open access and through subsidization (Milazzo 1998), and ecosystem structure and function are being compromised (Jennings and Kaiser 1998; Pauly et al. 1998). Nowhere is this more apparent that in tropical inshore fisheries where vulnerable species are often intensely exploited by artisanal fishers who use diverse, and sometimes destructive, fishing methods (Dalzell et al. 1996; Munro 1996; Johannes 1998).

The reasons for this breakdown in fisheries management are complicated. Marine ecosystems are poorly understood and there are fundamental uncertainties regarding the linkages between fishing and stock depletion (e.g. Jennings and Polunin 1996; Lipcius et al. 1997). In addition, social systems in tropical coastal areas can be very complex (Ruddle 1998; World Bank 2000) with intense competition over scarce marine resources. Even where the political will exists to manage coastal fisheries, governments and communities often lack the skills and resources necessary for effective management (Roberts 1997a). The conventional approach of optimizing biological or economic yield of a single species is clearly unsuited for tropical inshore fisheries, where target species are often highly vulnerable, ecological data are incomplete, fish landings undocumented, and/or property rights ill-defined (Roberts and Polunin 1991; Roberts 1997a; Johannes 1998; Coleman et al. 2000). This makes economically efficient policy tools such as transferable quotas impossible to implement for most tropical multi-species artisanal fisheries.

Ecosystem-based management (Christensen et al. 1996) has emerged as the primary alternative to the conventional fisheries management paradigm (Costanza et al. 1998; NRC 1999; Gislason et al. 
2000), and marine reserves are viewed as a central policy tool for implementing marine ecosystembased management (Bohnsack 1993; Roberts and Polunin 1993; Costanza et al. 1998; Murray et al. 1999; Halpern in press). For the purposes of this paper, we define marine reserves as no-take fishing reserves. Marine reserves address the main themes of marine ecosystem-based management by contributing to the maintenance of biodiversity and ecological processes that maintain resilience while enhancing fisheries, increasing opportunities for non-consumptive activities and building knowledge for improving coastal management (Costanza et al. 1998; Conover et al. 2000; Dayton et al. 2000).

Surprisingly, there is a scarcity of rigorous policy analyses of marine reserves (Carr 2000; Milon 2000) that demonstrate whether marine reserves lead to sustained socioeconomic benefits. Economic analysis is a well-established field and cost-benefit analysis (CBA) is commonly used to evaluate a wide variety of renewable resource policies and programs (Folmer and Gabel 2000; van Kooten and Bulte 2000). The guiding principles of CBA are simple: if the economic benefits (calculated by summing producer and consumer surpluses) of a policy exceed the costs, the policy is worthwhile and should be pursued, and that policies with higher ratios of benefits to costs should be pursued first to improve societal welfare. But to understand fully the economic impacts of marine reserves also requires accounting for transaction costs (e.g., planning and reaching agreements about marine reserve configuration and rules, monitoring, enforcement and ex post opportunism such as free riding and rent seeking) that are often ignored in standard economic analyses (Rudd et al. 2002). For tropical inshore fisheries, transaction costs may comprise a large proportion of total fishery management costs.

The challenges for policy analysts are twofold. First, from an empirical perspective, evidence quantifying the ecological benefits of marine reserves is relatively sparse because of the ad hoc design of many reserves (Alder 1996; McClanahan 1999) and the inherent difficulties of 
ascertaining causal linkages in the marine environment (e.g. Jennings and Polunin 1996; Paddack and Estes 2000). In addition, many of the ecosystem services that reserves provide are nonmarket in nature (Moberg and Folke 1999) and difficult to value, especially in developing countries where funds for economic studies are limited. Data on appropriately disaggregated costs of fisheries management and governance are also unavailable in many developing countries.

Second, from a theoretical perspective, there is a need to develop theory that causally relates marine ecosystem-based 'best practice' management, which incorporates local ecological knowledge and increases stakeholder stewardship through comanagement of local resources, to socioeconomic outcomes. This requires theoretically sound policy experiments that test and screen ecological and socioeconomic hypotheses (Walters 1997) and comparative studies that address causal complexity (Ragin 2000) and its impact on ecological and economic outcomes.

Our paper addresses both issues, although the main focus is on the second, linking tropical ecosystem-based fisheries management and recent developments in transaction cost economics and social capital theory. The role of social capital is particularly important for the development of research hypotheses about the efficiency and effectiveness of marine reserves versus other policy options under varying ecological and social conditions. Our goal is not to provide a guide to conducting marine reserve policy analyses per se but rather to facilitate policy analyses by identifying economic and social theory needed to conduct integrated ecological-economic analyses of marine reserves and the challenges in putting the theory to practice.

\section{Ecological Services and the Value of Marine Reserves}

How can we know which of many possible policy packages to implement, given multi-faceted and sometimes conflicting - societal goals? Whatever the ultimate goal, we do know that economic 
efficiency plays an important role in the evaluation of all policy options because a misallocation of society's resources will reduce overall social well being. If society chooses to put a high priority on marine conservation, implementing a high-cost policy that achieves the same end result as an alternative low-cost policy takes away resources from other social priorities. Each policy option has an opportunity cost: this implies that economic efficiency will always be an important evaluation criterion even when it is not the ultimate policy goal.

CBA involves tallying consumer and producer surpluses. Consumer surplus is the difference between what people are willing to pay and what they actually have to pay for an economic commodity. Likewise, producer surplus is simply the difference between a producer's total revenue and total variable cost or, at the margin, between price and marginal cost (with fixed costs considered sunk). Ecological amenities provided by marine reserves are also economic commodities and have a 'price', based on their marginal use and non-use values. Various types of nonmarket services generate consumer surplus even though they are not traded in established markets. Table 1 outlines the main types of economic values that need to be considered in economic analyses of marine reserves (see Dixon and Pagiola 1998; Cesar 2000).

$<<$ insert Table 1 about here $>>$

Research on the producer surplus of those who use marine reserve services as inputs in their businesses (e.g., artisanal fishers, sport fishing guides, dive charter operators) is complicated in developing countries and has been subject to even less examination than valuation of the flow of marine reserve services to consumers. Cost and earnings surveys would be needed to quantify producer surplus for specific situations. For many fisheries, producer surplus may be near zero as fishing revenue just covers the variable costs of fishing (Rudd et al. 2002). Thus, for many tropical 
artisanal fisheries, the majority of economic surplus is likely to consist of consumer surplus from various nonmarket and nonuse amenities.

Marine reserve costs can be substantial (Milon 2000) and are largely 'up-front' costs (e.g., planning, lost income) incurred before the long-run beneficial impacts of the marine reserve can be realized. By contrast, other policy options such as total allowable catch limits (TACs) that are mandated by government fisheries managers may have relatively low up-front costs but higher long-term costs (e.g., monitoring, enforcement). The choice of discount rate used in an economic analysis will, therefore, have an impact of the economic viability of conservation-oriented marine reserve policies.

In this section, we examine several ecological services that marine reserves might provide, how they can be valued, and some potential costs of marine reserves. We concentrate on three potential services: (1) larger and/or more abundant fauna within marine reserves boundaries; (2) emigration or 'spillover' of animals from reserves to adjacent fishing grounds; and (3) increased ecological resilience. Other ecological services are certainly possible (e.g., biodiversity preservation) and might provide a range of economic values outside the scope of the current discussion (see Dixon and Pagiola 1998; Moberg and Folke 1999; Cesar 2000). The three services we focus on have relatively local impacts and are possible - with varying degrees of difficulty - to assess empirically or with computer models. The nonuse economic value of biodiversity (existence value) is potentially large, but has limited policy relevance for most tropical marine reserves until compensation mechanisms are developed to transfer income from global beneficiaries of increased biodiversity to the local citizens who bear the costs of conservation (van Kooten and Bulte 2000). 


\section{Increased Size and Abundance within Marine Reserves}

Both commercial and subsistence fisheries tend to be size selective, often targeting large piscivores at the top of the trophic chain (Roberts 1997a). A reduction in fishing pressure within marine reserves is hypothesized to lead to an increased abundance of fish that are, on average, older and larger than would be the case in the presence of fishing (Polunin and Roberts 1993; Jennings 2001). This in turn would lead to greater average fecundity and therefore greater gamete production within marine reserves than within similar areas of unprotected habitat (Roberts and Polunin 1991). Empirical evidence supporting the hypothesis that marine reserves increase the size and/or abundance of many valuable species within marine reserves is substantial (Roberts et al. 2001; Halpern in press). In general, reserves tend to lead to increases in size and/or abundance for benthic shellfish and carnivorous finfish that are relatively sedentary (Conover et al. 2000; Tupper and Rudd in press). For fishes lower on the trophic chain, there can be complications because the protection of top-level piscivores might cause decreases in abundance of some prey species (Tupper and Juanes 1999). The evidence for indirect effects of fishing on community structure is inconclusive (Jennings and Polunin 1997; Jennings 2001), although some evidence exists for "second-order effects" where removal of top-level carnivores, such as large groupers, results in a proliferation of smaller species (Watson and Ormond 1994; Chiappone et al. 2000).

Undisturbed marine reserve environments may provide valuable information (quasi-option value) for commercial fishery managers by allowing scientists to better estimate life history parameters (e.g., growth and natural mortality rates) necessary for accurately modeling fisheries and developing appropriate policies in unprotected areas. Given the potentially large economic benefits that could result from better management of capture fisheries, the value of information could be substantial although this issue remains essentially unexplored. 
A second economic benefit of having larger or more abundant animals within marine reserves derives from non-extractive use values. It is known that snorkelers and divers often prefer viewing 'big stuff' and 'icon' species (Williams and Polunin 2000). Research to has demonstrated that divers significantly prefer viewing larger and/or more abundant spiny lobster (Rudd 2001) and Nassau grouper (Rudd and Tupper 2002), species that might benefit from marine reserves.

Similarly, economists have found that 'flagship' or icon species such as elephants and rhinoceros have value in attracting tourists ( see van Kooten and Bulte 2000).

On the production side of the equation, effects of changes in animal sizes or abundance will likely change the behavior and profitability of recreational service providers and may increase producer surplus (see Rudd et al. 2002). Cost and earnings data required to assess industry profitability is usually not available for business sectors using tropical marine reserves but must be collected in the future to better quantify this portion of the economic value of ecological services. Marine reserves may induce changes in visitation, potentially leading to congestion effects (Davis and Tisdell 1996) where people's willingness to pay for wildlife viewing declines due to the number of other people partaking in the same activity (Rudd and Tupper 2002).

\section{Spillover from Marine Reserves to Adjacent Commercial Fishing Grounds}

As the density of fish within a marine reserve rises due to protection, fish should theoretically 'spillover' reserve boundaries in density-dependent emigration to adjacent areas that are open to fishing, thus increasing yields for fishers in those areas. While the basic intuition may be simple, the habitat carrying capacity must be reached as a result of protection before density-dependent spillover is likely to occur (Lizaso et al. 2000). There is also a balance to strike between reserve boundary porosity and protection. When boundaries are too porous, there may be no advantage to 
protecting an area; conversely, when boundaries are impermeable, spillover to adjacent fisheries will not be possible. Contiguous habitat is most conducive for spillover (Roberts 2000), but in practice marine reserve design has often been based on geographic features that limit spillover (e.g., Rudd et al. 2001).

Alternatively, spillover may occur via random movements, independent of resident fish density, if the home range size of the fish is larger than the area of the marine reserve (Kramer and Chapman 1999; Tupper and Juanes 1999). In general, larger fishes have larger home range sizes (Zeller 1997) and are more likely to cross reserve boundaries, while smaller species tend to have small home ranges and may spend all their time within marine reserve boundaries (Holland et al. 1993). However, if the home range of the species is much larger than the reserve, the reserve may provide limited benefits to that species at best (Tupper and Rudd in press).

Evidence for spillover is limited (Russ and Alcala 1996, 1998; McClanahan and Mangi 2000; Roberts et al. 2001; Tupper and Rudd in press), although there is anecdotal evidence of fishers concentrating effort near reserve boundaries (Lizaso et al. 2000). It is generally unknown whether spillover from marine reserves will be sufficient to offset lost catches from closed fishing grounds. The market price for fish emigrating out of marine reserves is easily documented, although analysts must be cognizant of possible market price distortions in tropical fisheries. For example, tariffs on imported seafood products distort local markets for Nassau grouper in the Turks and Caicos Islands, leading to artificially high prices (Rudd in press).

As a result of the difficulty in experimentally quantifying spillover, there has been substantial modeling effort directed at this phenomenon (see Rodwell and Roberts 2000, Sumaila et al. 2000). The results are mixed and depend upon assumptions about dispersal, life stage, boundary porosity, fishing mortality, and fishing effort reallocation. Sladek Nowlis and Roberts (1999) found that 
marine reserves could increase and stabilize landings in adjacent commercial grounds if properly designed. In a model of Hong Kong marine fisheries, Pitcher et al. (2000) showed that boundary porosity (and fish migration speed) had a strong influence on the success of marine reserves. Reserves of up to $20 \%$ of the fishing ground area could significantly increase returns to commercial fishers. Stockhausen et al. (2000) and Sanchirico and Wilen (2001) examine the possibility that marine reserves can provide a 'double dividend', where spawning biomass increases within reserves while harvest increases adjacent to reserves. In both models, the success of marine reserves in providing a double dividend depends on a number of specific model parameters, including boundary porosity.

Several important considerations will influence the producer surplus of fishers utilizing spillover from marine reserves. First, have costs of fishing increased or decreased as a result of the marine reserve? The implementation of a reserve can increase producer costs if fewer fish are available due to access restrictions, if there are higher fuel or labor costs to fish farther afield, or there is increased congestion on the fishing grounds. Alternatively, it might lower costs if there is a steady and reliable outflow of fish from a reserve to adjacent fishing grounds. The economic value of spillover depends not only on biological factors, but as much or more so on the behavior of fishers and the cost of fishing, neither of which is adequately considered in many biological models that incorporate ad hoc fisher behavior (Wilen et al. 2002). Further, in density-dependent systems, the cost of fishing may influence whether a single marine reserve is a 'source' or 'sink' relative to adjacent fishing areas (Sanchirico and Wilen 2001). High intrinsic growth rates in areas with abundant essential fish habitat may also make it more expensive to close a productive fishing ground due to higher opportunity costs for fishers.

The models demonstrate that calculating the economic costs of marine reserves is not a simple matter. Recent advances in spatial econometrics and spatially explicit modeling (e.g., Smith 2000; 
Walters 2000; Folmer et al. 2002; Wilen et al. 2002) should spur further research in the various approaches to this problem.

\section{Increased Ecological Resilience due to Marine Reserves}

\section{Trophic Effects}

Fishers usually target commercially valuable piscivores that are high on the trophic chain. As valuable piscivores are depleted, there can be increasing pressure to harvest species lower on the food chain (Jennings and Polunin 1996; Pauly et al. 1998) and to engage in more destructive fishing measures. As fishing pressure increases, herbivores and algae may come to dominate degraded tropical inshore systems (McManus et al. 2000), reducing ecosystem resilience and leaving them even more vulnerable to anthropogenic and natural stresses and shocks.

Marine reserves are thought to help preserve resilience by protecting key species and habitat, thus leaving ecosystems with more capacity to resist stresses (Green et al. 1999). The field evidence for this assertion is ambiguous, however, due to the complexity of tropical inshore ecosystems. Finescale experimental evidence supports the hypothesis that predator removal will impact reef ecosystems (Carr and Hixon 1995), but broader scale research has shown that tropical systems can be quite resilient because of the complexity of the ecosystem and overlapping niches for many species (Jennings and Polunin 1997; Russ and Alcala 1998). Marine reserve modeling, on the other hand, provides support for the hypothesis that marine reserves lead to increased functional resilience within and outside of the reserves (Guénette and Pitcher 1999; Pitcher et al. 2000; Walters 2000). 


\section{Effects of Connectivity}

In addition to increasing ecological resilience locally by maintaining ecosystem structure and function, marine reserves may contribute to the maintenance of ecosystem services in downstream 'sinks'. Due to the broadcast nature of spawning for most tropical species, which disperse larvae on ocean currents, there is potential for widespread larval export beyond reserve boundaries (Roberts 1997b). In theory, more larval dispersion from marine reserve 'sources' should lead to more juveniles and adults in the future in downstream 'sinks', thus helping to maintain species balance and ecosystem resilience. Whether or not this is, in fact, the case depends on assumptions about larval behavior, mortality and post-settlement factors. If larvae suffer high mortality and are widely dispersed, larval supply may only rarely saturate reefs and leave enough recruits that densitydependent growth or mortality occurs (Doherty and Fowler 1994). As a result, adult year-class strength will depend mainly on larval input. If, on the other hand, most of the mortality occurring in recruits is due to post-settlement processes, larval and adult production may be spatially and/or temporally decoupled (Hixon and Carr 1997; Lipcius et al. 1997; Tupper and Boutilier 1997).

In addition to local oceanographic conditions that may favor retention of larvae near their natal reef (Sammarco and Andrews 1998; Jones et al.1999), recent field studies suggest stronger than expected self-recruitment due to the swimming capacities and vertical migrations of larvae (Leis and Carson-Ewert 1998; Bellwood and Fisher 2001). Mora and Sale (2002) conclude, however, that the extent to which coral reef fish populations are closed or open is currently unknown, but that open populations are likely in many environments. The extent to which marine reserves can protect self-recruiting populations or enhance downstream fisheries thus will likely be highly site and species specific. Even low levels of larval export should greatly reduce the probability of extinction of some marine species. 


\section{Valuing Resilience}

Due to the complexities of field studies, core insights into the economic value of resilience for marine systems may come from modeling. Larval export is a very important marine reserve benefit in a number of models (Man et al. 1995; Stockhausen et al. 2000) but depends strongly on modeling assumptions. Mass-balance models developed using Ecopath (Walters et al. 1997; Pitcher et al. 2000; Walters 2000) show promise for transdisciplinary analyses of ecosystem resilience and valuation of future ecosystem production under various degrees of risk and ecosystem robustness. Pitcher et al. (2000), for example, used biomass and catch data for 152 species in 7 gear sectors in a quasi-spatial mass-balance model and simulated the effects of a wide range of fishing pressures. They found that implementation of effective marine reserves led to a shift in species composition and a recovery in larger, more valuable demersal fishes at higher trophic levels.

How can the economic consequences of changes in resilience be valued? Marine reserves should be viewed as an insurance policy to protect basic ecosystem services and maintain resilience in the face of declining ecosystem capacity outside of protected areas. This marine service would be akin to that provided by terrestrial protected areas, where a range of studies demonstrate the importance of risk diversification to avoid pitfalls associated with spatially correlated catastrophic events (Gilpin 1987). Economic value is derived from the ability of a system to maintain the flow of ecological amenities given natural and anthropogenic shocks.

Perrings (1998) describes how the evolution of ecological-economic systems can be modeled as a Markov process in which the resilience of a system in any local stability domain is measured by the probability of transition to some other state. Different states will have differing capacities for the generation of ecological goods and services. Theoretically, use and nonuse values in the various states can be estimated and the change in expected value calculated for feasible transitions, which 
may be relatively few in number from step to step. Analyses of this sort have not yet been applied to marine reserves.

Perrings (1998) points out that the matrix of transition probabilities depends on initial conditions (properties of the system in a given state, including number of species), the disturbance regime and the social constructs that prescribe the possible uses for resources and structure feedback that determines how people react to environmental change. Because it is important to reduce the probability of transitions to undesirable states and/or increase the probability of transitions to desirable states, managers of tropical inshore systems must consider factors underpinning the resilience of the system. Valuing ecosystem resilience therefore requires establishing the role or species and processes and the social opportunity costs of those species and processes (Perrings 1998). Considering transition probabilities as policy targets then encourages the development of institutions that respond to environmental change through adaptive management.

\section{$\underline{\text { Transaction Costs and Marine Reserve Policy Analysis }}$}

Marine reserves are clearly an inferior policy alternative from an economic theory perspective: without concurrent effort controls, marine reserves can lead to rent dissipation if effort merely shifts farther afield or conflicts erupt over access to remaining fishing grounds. Economic arguments for

marine reserves hinge, instead, on pragmatic advantages relating to transaction costs - the costs of collecting information, negotiating and reaching agreements regarding the design and implementation of reserves, monitoring compliance, enforcing marine reserves rules, and ex post costs due to strategic behavior (e.g., 'free riding' and rent seeking). These factors - especially low monitoring and enforcement costs - are hypothesized to provide marine reserves with their 
comparative cost advantage relative to traditional management tools (Bohnsack 1993; Roberts and Polunin 1993; Murray et al. 1999; Roberts 2000).

In this section we first provide a brief overview of key concepts and terminology needed to address the issue of the transaction costs of marine reserve planning and management. Our focus is on institutions - the social norms and formal rules that shape and constrain opportunistic human behavior - and their impact on marine reserve management and, more broadly, tropical fisheries governance regimes.

We illustrate the utility of taking an institutional focus in the two subsequent sub-sections. First we consider the situation in which the formal governance system can be considered exogenous. The relevant question is: What is the most efficient policy package that can be used to achieve ecological, economic and social objectives in tropical inshore fisheries? The suitability of particular alternatives depends on matching the capacity of the policy package with the fisheries management problem. Policy analysts need to consider if/when marine reserves have a comparative advantage relative to other alternative policy options for fisheries management and conservation.

Next, we consider the situation where the formal governance system itself is endogenous. Here we consider the longer-term economic implications arising due to the governance regimes themselves. There is now widespread consensus that some form of comanagement (Pomeroy 1995; McCay and Jentoft 1998) will be needed for most, if not all, fisheries governance regimes. When the governance system is considered endogenous, the real policy question becomes: To what degree should tropical inshore fisheries management be decentralized or devolved from State to Community in order to most efficiently meet societal goals using marine reserves or other policy tools suited to local conditions? 


\section{Theoretical Background}

\section{Common Pool Resources and Common Property}

Maintenance of the flow of ecological goods and services from tropical reef systems pose a classic social dilemma. Society would be better off if more ecosystem services were produced, but it can be in an individual's self-interest to 'free ride' and shirk on investing in ecosystem services and/or engage in unsustainable use of services (i.e., the "Tragedy of the Commons"). Reef ecosystem goods and services usually have the characteristics of public goods or common pool resources (Figure 1).

$<<$ insert Figure 1 about here $>>$

Public goods are those for which use of the resource by one person or group does not leave others with less available to them (low subtractability) and for which there is difficulty in excluding nonauthorized users from harvesting the resource. Increases in ecosystem resilience, for instance, clearly can be characterized as a public good because one person's use of resilience does not diminish opportunities for others to share in the same benefits. If one group invests in measures to increase ecosystem resilience, it is virtually impossible to prevent others from benefiting from the investment. As a result, there is a general tendency for under-investment in public goods (Olsen 1965).

Common pool resources are those for which the use of the resource by one person or group subtracts from the stock of the resource so that others are left with less available to them (high subtractability) and by the difficulty of excluding non-authorized users from harvesting the resource. Most fish stocks would be characterized as common pool resources as harvesting would leave less fish available for others. 
It is important to differentiate between a type of resource (common pool resource) described in terms of physical characteristics and a type of property right (common property) described in terms of access and harvest rules (Ostrom 2000a). Common property is a type of property right in which a group of owners of a resource has a specified bundle of access and use rights. Common pool resources need not be managed using common property rights regimes; they may be effectively managed using private property rights or by the State. Much of the fisheries economics literature continues to conflate types of resources (public, private, common pool, toll goods), types of property rights regimes (individual, State, common property and open access - a situation where nobody holds property rights), and types of management organizations (firms, communal organizations and government agencies).

\section{Transaction Cost Economics}

There has been increasing recognition in the discipline of economics that social context is an important variable affecting economic efficiency. The field of 'transaction cost economics' explicitly considers the attributes of human actors and social embeddedness in research on the economic efficiency of different forms of governance organizations (Williamson 1999). While many ecologists (and sociologists) may find it surprising that economics has only recently recognized the importance of social context, it is important to understand that the discipline of economics has been built on rational choice theory. In its purest form, rational choice theory assumes individual decision makers have full information, unlimited cognitive capacity and choose to optimize their production or consumption activities given their production cost structure or preferences, respectively. This is relaxed in transaction cost economics; individual decision makers are assumed to exhibit 'bounded rationality', where their calculation skills are bounded by uncertainty, limited cognitive capacity, and spatially explicit local interactions. Thus, models of human decision-making tend to rely on heuristics and learning over time, rather than optimization. 


\section{Strategies, Norms and Rules}

Under a transaction cost economics approach, individuals exhibit goal-oriented and somewhat opportunistic behavior while going about their everyday lives within complex ecological and socioeconomic environments (Ostrom 1998). Because they have imperfect mental models of the world, people use strategies or heuristics based on prudence and experience to achieve personal goals. A smart person will adopt a behavior because that behavior is rewarded in their particular ecological or social context.

Johannes (1980), for instance, documents how South Pacific reef fish often form annual multispecies spawning aggregations. Fishers can take advantage of the predictable geographical and temporal concentrations of fish, and their unusual docility during spawning, to land large numbers of fish with minimal effort. For an individual fisher, it is a prudent strategy to fish an aggregation because the reward is high for a given level of effort. That effective fishing strategy can, however, be based on an incomplete or incorrect model of the world. Veitayaki (1998) points out that there is a common misconception amongst rural Fijians that fishery resources are not in danger because they have always been sufficient for subsistence in the past. Reef fish replenishment is believed to occur supernaturally, so there is no need for conservation. While a strategy of fishing spawning aggregations may be effective for a few individual fishers, the result can prove disastrous if too much fishing pressure is brought to bear on the aggregation (Coleman et al. 2000). The outcome is a social dilemma: all fishers and their community could derive greater long-run economic benefits by cooperating and exercising restraint.

Social norms often evolve to address social dilemmas (Ostrom 1999). A norm is "a pattern of behavior that is customary, expected and self-enforcing. Everyone conforms, everyone expects others to conform, and everyone has good reason to conform because conforming is in each 
person's best interest when everyone else plans to conform" (Young 1996: 105). Norms encourage or discourage certain actions (i.e., they alter the incentives for resource users) but do not rely on formal government enforcement mechanisms (North 1990). In some regions, norms are expressed in terms of local taboos on resource use (see Colding and Folke 2000).

Three of the most important broad-based human norms include equality, equity and reciprocity (Ostrom 1998). Under norms of equality, gains from a transaction should be shared equally in the absence of objective differences between individuals even though one party may have the opportunity to take more than their portion (Ostrom 1999). Norms of equity imply that a greater contribution by an individual to a social exchange should lead to greater returns. Reciprocity norms have an evolutionary basis (Hoffman et al. 1998; Ostrom 1998). An offer to share or assist by one person is accompanied by an expectation for reciprocity in a reasonable time frame. Thus, reciprocity is an investment having a short-term cost for an expected long-term gain. If the 'generous' behavior is not reciprocated, there are implicit or explicit threats of punishment. These norms are present across cultures to varying degrees; they do not require formal enforcement under law but form an important part of the de facto 'rules-of-the-game' by which fisheries are managed and governed.

Rules are prescriptions about behaviors that are required, permitted or prohibited by society that help solve social dilemmas by altering the expected payoffs for various individual goal-directed behaviors (Ostrom 1990; Ostrom et al. 1994). Formal rules go further than norms, explicitly specifying a sanction that is backed by a formal governance organization (whether at the village level or through an international treaty). Effective rules need monitoring and established sanctioning procedures, as they must provide a credible threat to alter the costs and benefits that individuals perceive for various actions. In extreme cases, individuals may also derive utility from 
breaking rules under governance regimes that are perceived as illegitimate (Crawford and Ostrom 1995).

When social norms do not reward constraint or when monitoring and credible threats of sanctions are ineffective, we see 'paper parks' where users violate marine reserve access rules with impunity (Alder 1996; McClanahan 1999; Mascia 2000; Rudd et al. 2001). Compliance with rules is most probable - and hence the transaction costs of management reduced - when there is congruence between norms and formal rules (Ostrom 1990; Mascia 2000). For example, the 1988 Samoan Fisheries Act recognizes local village fishery management by-laws (Zann 1999) and enhances the capacity of local communities to develop and enforce fishing regulations that are consistent with local norms and applied to both community residents and outsiders. This initiative has resulted in more security over resource use for villages and increased incentives for local conservation. As a consequence, almost 40 villages had chosen to adopt marine reserves as part of their local fisheries management plan by 1999 (King and Fa'asili 1999).

\section{Institutions}

Institutions are simply the interrelated rules and social norms that govern social relationships or, more informally, the 'rules-of-the-game' (North 1990). They are human constructs that craft mutual interdependencies, constrain the choice set that individuals face, and, thus, provide increased predictability for, and minimize conflicts between, individuals engaged in social transactions (Ostrom 1998). It is important to note that the definition of institutions held across the social sciences differs substantially from the everyday definition of institutions likely to be held by most fishery biologists, ecologists and managers. Institutions are not management organizations: organizations - firms, governments, civil society - are the 'players' that develop rules and shape 
norms in a democratic society so that social dilemmas can be solved in an effective and efficient manner.

\section{Social Capital}

The broad complex of social interactions, norms, rules and institutions are known as social capital (Woolcock 1998, 2001; Rudd 2000; Ostrom 2000b; Woolcock and Narayan 2000). Increasing levels of social capital increase the likelihood of successful coordination and cooperation needed to solve social dilemmas and, hence, reduce transaction costs.

Consider the well-known case of Apo Island, Philippines (Russ and Alcala 1996, 1998, 1999) where the local community successfully implemented a marine reserve. Fish density and biomass increased within the reserve and fishing improved outside it. The ecological services flowing from the marine reserve resulted in a long-term stream of economic benefits to local residents that they would not have otherwise enjoyed. Without the community norms and social networks that prevented opportunism on Apo, it is virtually certain that all economic rents would have been dissipated under de facto open access conditions (i.e., no rules). At nearby Sumilon Island, breakdowns in management - caused in part by a lack of trust between the community and outsiders, and in part by local politicians engaging in opportunism - led to depletion of fish stocks and dissipation of resource rents that might have been collected had there been cooperation.

Social relationships themselves can be viewed as assets that contribute to the production of human well being. In a study in rural Tanzania, Narayan and Pritchart (1999) found that the effects of group or association membership of village residents were large, with one standard deviation increase in membership leading to household expenditure increasing by $20-30 \%$ (as large as the tripling of education levels). Internationally, Knack and Keefer (1997) examined 29 market economies and found that investment and growth rates were higher in countries where interpersonal 
trust and norms of civic cooperation were greater. They also found that trust and cooperation are stronger in countries with well-developed legal and institutional infrastructure protecting property and contract rights, and in countries that are relatively homogenous in terms of income level and social standing. More recently, Uphoff and Wijayaratna (2000) documented how social capital helped residents capture gains of up to US \$20 million by facilitating water sharing arrangements that led to increased productivity during a 1997 drought in Sri Lanka.

It is useful to consider two forms of social capital (Uphoff and Wijayaratna 2000). Structural social capital consists of the rules, procedures, and protocols that make it easier for people to work together to achieve mutually beneficial collective action. Cognitive social capital consists of the norms and values that people hold and which predispose them to cooperate with each other for mutually beneficial collective action. Social capital can function on three levels, as an asset that can be used for 'linking' (Woolcock 2001), 'bonding' or 'bridging' (Woolcock and Narayan 2000). Linking results when local residents have increased access to decision makers. For instance, dense kin and social networks in the Turks and Caicos Islands (Bennett et al. 2000) allow rural fishers access to senior government decision makers that would otherwise be unavailable in regions with less interconnectedness. Bonding results when strong intracommunity ties give kin and communities a sense of identity and common purpose. Bonding social capital is especially important for the rural poor because it serves as a substitute for the State when citizens are deprived of basic services.

Bridging results when communities endowed with diverse intercommunity ties are in a stronger position to confront problems and take advantage of economic opportunities. In Samoa, the government has worked closely with village councils to develop national legislation that supports local fisheries management (Zann 1999) and has provided extension officers to assist councils develop local management plans (King and Fa'asili 1999). The rapid adoption of village 
management plans and a surprisingly high number of village marine reserves is indicative of bridging social capital, where ideas and information have flowed between villages. All villages that are part of the network may benefit, increasing their capacity for solving local social dilemmas by learning about their marine resources and about how to monitor and enforce their village rules.

\section{Comparative Policy Analysis of Marine Reserves}

Different policy instruments may be used to achieve any given social goal. The suitability of particular alternatives depends on matching the capacity of the policy package with the fisheries management problem that is, in part, defined by its social and institutional context (Ostrom 1990). Current marine reserve management research consists largely of single-case or small- $n$ comparative studies (e.g., Fiske 1992; Polunin and Roberts 1993; Russ and Alcala 1999; Chiappone and Sulivan Sealy 2000; Mascia 2000). This is typical of common property research on fisheries, forestry, irrigation and agriculture, where case studies play an important role in furthering our understanding of mechanisms that link specific ecological and social systems.

Despite their individual importance, many case studies of renewable resource systems exhibit two potential weaknesses. McCay and Jentoft (1998) and Agrawal (2001) emphasize that some studies have not sufficiently accounted for aspects of the ecological, cultural and institutional context, or power relationships. Such 'thin' studies often end up broadly advocating simplistic solutions for renewable resource management. Secondly, awareness of the theoretical relevance of causal variables or systematic tests of causality are lacking in many studies (Agrawal 2001). Conclusions about the universality of local findings (i.e., the effectiveness and efficiency of protected areas) may, therefore, be overstated or overly simplistic. Agrawal (2001) concludes his review of common property management research with a plea that researchers should emphasize "multiple tests of 
several theories [in] carefully conducted, deeply engaged comparative studies" (p. 1665). Marine reserve analysts should heed this advice.

When conducting a comparative policy analysis, the goal is to ascertain how (1) various policies will differentially impact individual incentives and behavior and (2) how aggregate patterns of behavior arising from various policies impact ecological and socioeconomic well being. While a range of socioeconomic variables may be important for a comparative analyses, two facets of social capital are of particular interest for marine reserve policy analyses: micro-level 'community capacity' (i.e., the ability of the community to use social networks and norms for mutually beneficial collective action); and macro-level 'institutional capacity' of the government (i.e., the ability of the government to provide public goods and assure that property rights are honored).

An argument can be made that both community and institutional capacity are needed if marine reserves are to be successful. Without adequate community capacity, the norms that constrain opportunism are absent and widespread cheating is likely to negate any benefits that marine reserves might provide (Fiske 1992; Russ and Alcala 1999; Mascia 2000; Rudd et al. 2001). Without institutional capacity, communities that wish to initiate reserves to solve local social dilemmas will be unable to legally exclude outsiders from free-riding on their efforts (Cooke et al. 2000).

Community-level social capital and formal State -level institutions can act as substitutes to some extent. When government and community are both strong, social capital can play a bridging role and help community residents achieve higher levels of well being. In tropical developing countries, where formal institutions are often relatively weak, social networks remain important for solving social dilemmas such as inshore fisheries management (Sutherland 1986; Ruddle 1998; Bennett et al. 2000; Cooke et al. 2000; World Bank 2000). If the State lacks capacity, high levels of local 
social capital can compensate to some degree, helping communities cope with fisheries selfgovernance even in the absence of formal state support. If the State is strong but social capital at the community level low, citizens may become disengaged and expect that government fisheries departments will solve fishery management problems because 'that is their job'. When both the government and community have low capacity levels, resource destruction is virtually guaranteed under de facto open access.

\section{Social Capital and Fisheries Management - Three Cases}

Relatively capable communities and government have co-existed in Belize for several decades (Sutherland 1986; Mascia 2000). Fishers have a history of collective action going back to the 1960 formation of the Northern Fishermen Cooperative Society, an organization formed to contest the market power of foreign lobster buyers. Government is relatively capable by Caribbean standards and has been generally supportive of the cooperative movement. Local lobster and conch fishers have been able to collect substantial economic rents, investing in their own processing plants and diversifying their fishing activities.

Coastal Belize is not pristine, but compared with much of the Caribbean is ecologically intact despite export-oriented commercial fisheries. In general, however, Belizean fishers have been successful in maintaining commercially viable valuable conch and lobster stocks and capturing substantial resource rents. Marine reserves have enjoyed strong support from local residents (Mascia 2000) and the backing of government; as a result, marine reserves such as Hol Chan are held up as an example of the ecological and economic benefits reserves are capable of providing (Polunin and Roberts 1993; Mascia 2000).

Contrast this to the situation in the Turks and Caicos Islands. There is a national system of marine reserves in the Turks and Caicos, but there was little community input in the design process (Rudd 
et al. 2001). A government fisheries department manages export-oriented spiny lobster and queen conch fisheries using conventional fishery management models. Although government resources are limited, historical fisheries landing records are extensive and institutional capacity is relatively high by Caribbean standards due to British technical support. Community capacity in the islands is low, however, and there is no evidence of cooperation and self-restraint to solve local social dilemmas. Just the opposite, in fact, appears true. The opening of lobster season has a local name, "The Big Grab", that illustrates (Rudd et al. 2001). Economic rents are dissipated due to the widespread illegal harvest of undersize, immature lobsters (up to 95\% undersize from some popular fishing grounds early in the fishing season). Overall economic returns could be increased greatly if fishers could cooperate and exercise restraint in the early season and spread the lobster harvest out over an extended season.

In Fiji, some strong traditional fisheries management systems are still intact (Veitayaki 1998; World Bank 2000) but the Fijian government plays a relatively limited role in the management of inshore reef fisheries in many parts of Fiji due to their limited resources and inter-governmental jurisdictional conflicts (Cooke et al. 2000; Virdin 2000). Many communities in Fiji are left more or less on their own; even though they possess high levels of social capital, their asset is used for bonding purposes, helping to cope and manage local Customary Fishing Rights Areas (CFRAs) without strong government support. Veitayaki (1998) provides an illustration of how structural and cognitive social capital co-exist in traditional Fijian fishery management and help communities cope when the State is weak:

"Traditional management arrangements are enforced through traditional authority, which means that there are protocols to be followed. The social structure and closeknit units in Fijian communities demand that people strictly follow tradition and respect each other. Decisions made by the group are often conveyed through the social channels of communication, which ensures that all those involved are made aware of the group's decisions. Consequently, the traditional system of retribution 
is an effective way of ensuring compliance. Nonconformists are treated harshly, and this is an effective deterrent to others..." (p. 52).

The Votua CFRA provides an example of a community with high management capacity, but limited support from government (Cooke et al. 2000). Three clans share management of the region and are highly motivated to manage the fishery effectively because the CFRA is their only source of revenue. Community-based management and enforcement have helped these clans cope while they function in relative isolation; threats of physical violence may have to be used to ensure local compliance with the CFRA.

Poaching is more common in other parts of Fiji where community management is less aggressive, fishing grounds are close to urban areas or the clan with ownership rights to a CFRA does not live adjacent to the fishing grounds (Veitayaki 1998). Rural Fijians perceive increased overfishing, poaching and destructive fishing to be major threats to inshore fisheries viability (World Bank 2000) but some CFRA owners feel powerless to stop the poaching because of the lack of formal institutional backing (Cooke et al. 2000). As a result, community members in some parts of Fiji are passive observers of government fishery managers (Veitayaki 1998) who possess neither the resources nor local knowledge to manage inshore fisheries.

\section{The Importance of Social Capital in Analyses of Marine Reserves}

Why does social capital matter for marine reserve implementation and management? We maintain that it matters because conclusions about the suitability of marine reserves as an efficient policy tool will only hold under a certain set of community and institutional conditions. When there is a high level of local social capital and an institutional backstop that provides legally binding sanctions that enable exclusion of non-authorized users, community-based marine reserves may well hold a comparative advantage over other policy tools. While locally managed marine reserves may be a 
preferred policy tool in Belize, what about the Turks and Caicos where community capacity is low, Fiji where institutional capacity is limited, or other regions where both community and institutional capacity is lacking?

Where there is community apathy, as in the Turks and Caicos, we would hypothesize that a community-based marine reserve management strategy is likely to fail, due to widespread cheating because there are few internal social sanctions against individual opportunism. We might expect to see more efficient policy tools that rely less on local community capacity and more on enforcement by a stronger central authority in the short term. In such an environment, there is an important role for education programs and norm-seeding activities by government and, perhaps more importantly, by civil society organizations. Without first building community capacity and increasing levels of trust to such an extent that mutually beneficial collective action is feasible, investments in marine reserves - that depend on local norms of compliance - are likely to provide lower returns than investments in community capacity building.

When institutional capacity is limited, as in Fiji, local leaders may feel powerless trying to use traditional sanctions on fishers from outside their own community. Hence, we might hypothesize that community-based marine reserves would be successful where the local fishery is relatively isolated from potential poachers or where fisheries income is important to the community, justifying independent monitoring and informal enforcement measures. Policy interventions might best focus on institutional strengthening in such circumstances (e.g., educating decision-makers, coordinating policies between government agencies and increasing the capacity of the court system to uphold rules), or increasing the salience of fisheries conservation and management to the local community. 
When both institutional and community capacity are lacking, external governments and environmental NGOs may face a daunting task to even reach a point where marine reserves can be considered as a policy tool for fisheries management and conservation.

\section{Causal Complexity in Comparative Analyses of Marine Reserves}

As important as social capital is in the comparative analysis of policy options for fishery management and conservation, it is by no means the only causal variable influencing the potential viability and economic efficiency of marine reserves. As additional causal variables are considered in a comparative analysis, the number of distinct case types rises exponentially. Ragin (2000) points out that case types that vary in only one attribute can be completely different in nature.

The research challenge in comparative policy analysis arises because there will be no simple blanket policy prescriptions for all situations. A policy prescription for a case in one fishing ground with attributes $\mathrm{x} \times \mathrm{x} \mathrm{y} \times \mathrm{may}$ be different than for a neighboring area with attributes $\mathrm{x} \times \mathrm{y} \mathrm{x}$. The power of the comparative institutional approach derives from the fact that there may be other fisheries, perhaps in different parts of the world, that share the same set of attributes $\mathrm{x} \times \mathrm{x} \mathrm{y} \mathrm{x}$ with the first fishing ground. If these are considered as a group, a theoretically-based comparative approach has the potential to identify robust kernels of 'truth' about the effectiveness of policy prescriptions for particular case types, independent of the geographical location of the particular case instances (e.g., Hellström 2001). Broad-based comparative analyses that incorporate explicit links between causal variables chosen on the basis of ecological and social theory, on the one hand, and ecological and economic outcomes on the other hand, are needed for marine reserves.

In summary, we should expect that there are situations when marine reserves are preferred policy tools but that there are also situations where they will not be the most efficient policy option for fisheries conservation and management. Analysts must be willing and able to explore a full range 
of options and recommend those that most efficiently achieves social objectives. In some cases, the most efficient policy option will be education or other forms of community and/or institutional capacity building that enable marine reserves to eventually be more effectively implemented. This process is a long-term effort and leads us to consider the endogeneity of the system of governance itself.

\section{Economically Efficient Fisheries Governance Regimes}

For longer-term marine conservation and management initiatives, analysis at the constitutional choice level becomes important. At the constitutional level, choices are made about whom is entitled to make lower level rules and how the rule-making process itself is governed (Ostrom 1990). Thus, the structure of governance - the private sector, public sector and civil society organizations and institutions that help a society to steer itself (Hubbard 2000) - can be viewed as endogenous.

Governance regimes that are based primarily on individual property rights are likely inappropriate for virtually all inshore tropical systems due to the importance of the suite of nonmarket ecological amenities they provide and the difficulty of matching ecological and management scale under private property rights. The importance of traditional community-based property rights in tropical artisanal fisheries is, however, widely recognized (Graham and Idechong 1998; Ruddle 1998; Veitayaki 1998; Zann 1999; World Bank 2000). Fishing most often requires consideration of large physical areas suited to communal property rights because of the fluidity of the environment and economies of scale in management. For instance, in Fiji, most CFRAs are managed at the aggregate clan level (vanua or yavusa) rather than at the sub-clan level (mataqali) (Cooke et al. 2000), and there is often cooperation where yavusa cooperatively manage larger CFRAs (Ruddle 1995). 
Ruddle (1998: 107) notes that "it is commonly asserted, although still largely undemonstrated, that traditional community-based systems of inshore fisheries management offer a modern management alternative [to State regulation]... [and] the devolution of control over natural resources would likely reduce the social, political, legal, conservation-related and management cost problems to be addressed by central or provincial governments". That is, there may be broad transaction cost advantages for community-oriented comanagement of tropical inshore systems.

\section{The Proper Scope of Governance}

A major research focus within transaction cost economics addresses questions of the 'proper scope of government' (Picot and Wolff 1995; Hart et al. 1997; Williamson 1999) and the efficiencymaximizing governance balance between the 'State' and the 'Market'. Because of the growing emphasis on comanagement and the use of marine reserves in tropical fisheries (e.g., White et al. 1994; Pomeroy 1995; Virdin 2000), the focus of research on the proper scope of governance for fisheries systems should more properly examine the balance between the 'State' and 'Community'.

Two options exist for incorporating local input in fisheries governance systems. Devolution of governance involves the transfer of decision-making authority to local communities, implying that they share in decisions about reserve design and fisheries management rules. Decentralization of power, on the other hand, involves shifting decision-making to local branches of government. Local government agents, who are presumably more aware of the unique local social and natural environment, may be able to tailor policies that are more consistent with local norms than a central government agency would be able to.

The degree of devolution/decentralization that minimizes transaction costs of governance depends on a number of factors. Williamson (1985) developed the 'discriminating alignment hypothesis', which postulates that transactions have certain attributes that affect transaction costs and that 
governance systems have certain competencies and costs. Minimizing societal transaction costs requires that these two factors be aligned. The transaction of interest in tropical inshore fisheries is the production and maintenance of reef environmental quality that provides a flow of ecological amenities. The transaction costs of producing or maintaining reef environmental quality include: the costs of environmental monitoring of reef conditions and fish stocks; discussing, developing and reaching agreement on rules (i.e., reserve design and access) to control resource use; the legal costs for implementing management solutions; ongoing monitoring costs to ensure compliance with the final policy package; and the costs associated with enforcing penalties for those who violate the rules.

\section{Impacts of Uncertainty on Transaction Costs and Governance}

For tropical artisanal fishery management, uncertainty is the key characteristic of the reef environmental quality transaction. Many tropical systems have been managed locally historically and fishers may have a very good idea of how fish behave, spawn and migrate (Johannes 1980). If fish production is predictable in time and space, and there is a tight coupling between adult abundance and recruitment, then users and managers can know and predict what resource withdrawal can be permitted and management at the local level should be more effective than centralized governance. The orientation in this situation would tend to be more on economic optimization rather than conservation per se (Ruttan 1998).

As uncertainty increases and managers are less able to predict either the causes or consequences of resource fluctuation and use, the goal of governance should tend more to insurance functions. Thus, we would hypothesize that the transaction cost minimizing balance in comanagement would shift increasingly towards the State as uncertainty rises, scientific research becomes more important, and the consequences of ecological degradation have external effects in other regions or other sectors of 
the economy. When demographic pressure increases, new markets open for non-traditional seafood products, or local communities have not been able to demonstrate that local social norms have controlled opportunism, then there may be a justification for a stronger public role in comanagement.

For instance, the maintenance of giant clam (Tridachnidae) stocks is a transaction that requires local knowledge because it is highly site specific, with subtleties that can only be appreciated with very detailed local knowledge. This raises an interesting policy puzzle: why, if the production of giant clam has characteristics that would at first seem to make it amenable to community-based management using marine reserves, are giant clam stocks so depleted (Dalzell et al. 1996) even in areas where community management is used to successfully manage vulnerable reef fish (Jennings 1998). One possibility is that the very high market prices for giant clam have altered incentives for individuals to such an extent that even traditionally strong local management systems have simply been overwhelmed and social norms supporting conservation have broken down. In addition, giant clams are inherently vulnerable: they are stationary, easy to harvest, slow growing and have limited larval dispersal (Lucas 1994), so the maintenance of stocks may be considered an unpredictable transaction. A counter argument could then be made for stronger precautionary State management as insurance against catastrophic stock decline. Of course, this argument requires a government with the capacity to provide strong management.

It is easy to see that there may be less than desirable compromises to be made and that neither State nor Community governance may be ideal without substantial capacity building efforts. One can also see that there are numerous feasible research hypotheses that emerge when the fisheries management problem is framed in terms of uncertainty, social capital and transaction cost economics. 
In summary, the success of devolution for marine ecosystem-based management depends on a number of factors. Community-oriented comanagement is likely to be efficiency-maximizing when the maintenance of reef quality requires local knowledge, when uncertainty regarding the causes and consequences of environmental change is relatively low, and when social norms and reputation can be used effectively to counter opportunistic behavior. Decentralized State governance may be more appropriate, however, if local knowledge is required but Community capacity is low. Social capital is an appropriate indicator of the extent to which user-managers of fishery resources are able to overcome social dilemmas and of the potential of marine reserves to efficiently achieve ecological and economic objectives. Thus, social capital is an important consideration in first identifying economically efficient policy options using comparative policy analyses and, second, as an indicator of the likelihood of successful efficiency-maximizing devolution or decentralization of governance systems over the longer-term.

\section{Concluding Remarks}

Marine reserves are seen as a central tool for implementing marine ecosystem-based management (Bohnsack 1993; Roberts and Polunin 1993; Costanza et al. 1998; Murray et al. 1999). The rationale for marine reserves is usually based on their potential for conserving or enhancing ecological amenities that provide a suite of market and nonmarket values while simplifying and reducing the costs of management. To date, however, there have been too few rigorous policy analyses of marine reserves to assess if reserves are, in fact, efficient policy tools for tropical inshore fisheries conservation and management. If credible analyses are not undertaken, there is a danger that current enthusiasm for marine reserves may wane as economic performance fails to meet presumed potential. 
In narrowly focused economic analyses, the costs and benefits of commercial and subsistence fisheries from which participants derive extractive direct use value are emphasized. The economic benefits of spillover from marine reserves are theoretically easy to measure because market prices exist but, in practice, the difficulties in ecologically quantifying spillover (Lizaso et al. 2000) make economic valuation a challenge. Further, the costs of marine reserves to fishers have been poorly quantified to date and there has been insufficient consideration of fisher behavior (Wilen et al. 2002). This is an area of increasing research and one in which economic theory will play a central role.

Marine reserves provide broader benefits than just increasing fish stocks for capture fisheries (Moberg and Folke 1999; Cesar 2000). There is widespread recognition that marine reserves can provide a range of nonmarket values but research quantifying these values is limited. Fully accounting for the range of nonmarket economic benefits of marine reserves may help counter short-run pressure favoring fisheries over conservation but that leads to the dissipation of long-run economic benefits if poorly managed. Where marine tourism potential exists, the non-extractive economic value provided by rapid buildup of icon species (Halpern in press) within marine reserves may provide especially important short-run economic benefits for local communities and help bridge the gap until long-term benefits become apparent (Rudd 2001).

Many of the arguments for marine reserves are based on the perception that the transaction costs of management - especially monitoring and enforcement - are lower for reserves than for other options. Policy analyses that go beyond the scope of standard CBA are needed to assess these claims. At the first level of analysis, when the existing governance regime is essentially fixed, the focus of a policy analysis is on the cost-minimizing policy package that achieves society's ecological and socioeconomic goals. Cost minimization requires that analysts consider recent theoretical developments showing how social capital can have a direct impact on the transaction 
costs of tropical fisheries management. Social capital makes it easier for individuals to trust others, increases the likelihood of cooperation, and thereby lowers the costs of maintaining the flows of ecosystem amenities from public goods and common pool resources.

The level of Community capacity (the ability to use social capital for mutually beneficial collective action) and State capacity (the ability of the government to provide public goods and assure that property rights are honored) in a region will substantially influence marine reserve effectiveness and efficiency. We hypothesize that both are necessary for deriving full benefits from marine reserves and that where one or both components of the equation are missing, policy tools other than marine reserves will be more efficient.

At a higher level of analysis, a focus on social capital and transaction costs also permits rigorous examination of the core marine ecosystem-based management tenet of comanagement.

Ascertaining the proper scope of governance - the efficiency-maximizing balance of the 'State' and the 'Market' - is currently a central issue in the transaction cost economics research agenda (e.g. Hart et al. 1997; Williamson 1999). A string of highly publicized fishery collapses has already moved fishery management research from a narrow subdivision of applied ecology to the forefront of the debate over resource management and policy (Conover et al. 2000). An opportunity now exists to move tropical marine reserve research into the mainstream of the transaction cost economics research agenda by rigorous analysis of the efficiency-maximizing boundaries between the 'State' and 'Community'.

There are analytical challenges in following this policy analysis strategy, of course. The questions regarding what causal variables to consider needs to be guided by theory and structured so that testable hypotheses are developed. Substantial guidance on which factors should be considered and their a priori effects is now available from the common property literature (Agrawal 2001). Recent 
advances in survey methods for measuring social capital (Uphoff and Wijayaratna 2000) and new methodologies such as Ragin's (2000) fuzzy qualitative comparative analysis hold promise as tools for integrating broad comparative analyses of marine reserve that address policy design and implementation issues that have regional or global relevance.

In conclusion, we believe that nonmarket valuation, transaction cost economics and social capital theory will play an important role in marine reserve research over the coming years. Fisheries managers and ecologists need to be aware of relevant economic theory, terminology and empirical research directions and challenges given the increasing need for transdisciplinary marine reserve planning and assessment in complex ecological and social environments.

\section{Acknowledgements}

An earlier version of this paper was presented at the Putting Fishers' Knowledge to Work conference, UBC Fisheries Centre, August 2001. We gratefully acknowledge comments by conference participants and three anonymous referees. Thanks also to participants at the July 2002 NOAA-sponsored All Islands Coral Reef Economic Valuation Workshop who helped highlight the challenges and opportunities facing fisheries managers, ecologists and economists collaborating on economic assessments of tropical reef fisheries. 


\section{Literature Cited}

Agrawal, A. (2001) Common property institutions and sustainable governance of resources. World Development 29, 1649-1672.

Alder, J. (1996) Have tropical marine protected areas worked? An initial analysis of their success. Coastal Management 24, 97-114.

Bellwood, D.R. and Fisher, R. (2001) Relative swimming speeds in fish larvae. Marine Ecology Progress Series 211, 299-303.

Bennett, E., Neiland, A., Anang, E. et al. (2001). Towards a better understanding of conflict management in tropical fisheries: evidence from Ghana, Bangladesh and the Caribbean. Marine Policy 25, 365-376.

Bohnsack, J.A. (1993) Marine reserves: they enhance fisheries, reduce conflict, and protect resources. Oceanus (Fall 1993), 63-71.

Botsford, L.W., Castilla, J.C. and Peterson, C.H. (1997) The management of fisheries and marine ecosystems. Science 277, 509-514.

Carr, M.H. (2000) Marine protected areas: challenges and opportunities for understanding and conserving coastal marine ecosystems. Environmental Conservation 27, 106-109.

Carr, M.H. and Hixon, M.A. (1995) Predation effects on early post-settlement survivorship of coralreef fishes. Marine Ecology Progress Series 124, 31-42. 
Cesar, H.S.J. (2000) Coral reefs: their functions, threats and economic value. In: Collected Essays on the Economics of Coral Reefs (ed H.S.J. Cesar), CORDIO, Department of Biology and Environmental Sciences, Kalmar University, Kalmar, Sweden, pp. 14-39.

Chiappone, M. and Sullivan Sealey, K.M. (2000) Marine reserve design criteria and measures of success: lessons learned from the Exuma Cays Land and Sea Park, Bahamas. Bulletin of Marine Science 66, 691-705.

Chiappone, M., Sluka, R. and Sullivan Sealey, K. (2000) Groupers (Pisces: Serranidae) in fished and protected areas of the Florida Keys, Bahamas and northern Caribbean. Marine Ecology

Progress Series 198, 261-272.

Christensen, N.L., Bartuska, A.M., Brown, J.H. et al. (1996) The report of the Ecological Society of America Committee on the Scientific Basis for Ecosystem Management. Ecological Applications 6, 665-691.

Colding, J. and Folke, C. (2000) The taboo system: lessons about informal institutions for nature management. Georgetown International Environmental Law Review 12, 413-445.

Coleman, F.C., Koenig, C.C., Huntsman, G.R. et al. (2000) Long-lived reef fishes: the groupersnapper complex. Fisheries 25(3),14-20.

Conover, D.O., Travis, J. and Coleman, F.C. (2000) Essential fish habitat and marine reserves: an introduction to the Second Mote Symposium in Fisheries Ecology. Bulletin of Marine Science 66, $527-534$.

Cooke, A.J., Polunin, N.V.C. and Moce, K. (2000) Comparative assessment of stakeholder management in traditional Fijian fishing-grounds. Environmental Conservation 27, 291-299. 
Costanza, R., Andrade, F., Antunes, P. et al. (1998) Principles of sustainable governance of the oceans. Science 281, 198-199.

Crawford, S.E.S. and Ostrom, E. (1995) A grammar of institutions. American Political Science Review 89, 582-600.

Dalzell, P., Adams, T.J.H. and Polunin, N.V.C. (1996) Coastal fisheries in the Pacific Islands. Oceanography and Marine Biology: An Annual Review 34, 395-531.

Davis, D. and Tisdell, C. (1996) Environmental management of recreational scuba diving and the environment. Journal of Environmental Management 48, 229-248.

Dayton, P.K., Sala, E., Tegner, M.J. and Thrush, S. (2000) Marine reserves: parks, baselines, and fishery enhancement. Bulletin of Marine Science 66, 617-634.

Dixon, J.A. and Pagiola, S. (1998) Economic analysis and environmental assessment. Environmental Assessment Sourcebook Update 23, World Bank, Washington, D.C., 14 pp.

Doherty, P.J. and Fowler, A. (1994) An empirical test of recruitment limitation in a coral reef fish. Science 263, 935-939.

FAO (Food and Agriculture Organization) (2000) The state of world fisheries and aquaculture, 1999. FAO, Rome. [online at www.fao.org/DOCREP/003/X8002E/X8002E00.htm; last accessed 30 Aug. 02].

Fiske, S.J. (1992) Sociocultural aspects of establishing marine protected areas. Ocean and Coastal Management 18, 25-46. 
Folmer, H. and Gabel, H.L., eds (2000) Principals of Environmental and Resource Economics, 2nd edn. Edgar Alger, Cheltenham, U.K. 784 pp.

Folmer, H., Gabel, H.L., Gerking S. and Rose, A., eds (2002) Frontiers of Environmental Economics. Edgar Alger, Cheltenham, U.K. 417 pp.

Gilpin, M.E. (1987) Spatial structure and population vulnerability. In Viable Populations for Conservation (ed M.E. Soulé), Cambridge University Press, New York, pp. 126-139.

Gislason, H., Sinclair, M., Sainsbury, K. and O'Boyle, R. (2000) Symposium overview: incorporating ecosystem objectives within fisheries management. ICES Journal of Marine Science 57, 468-475.

Graham, T. and Idechong, N. (1998) Reconciling customary and constitutional law: managing marine resources in Palua, Micronesia. Ocean and Coastal Management 40, 143-164.

Green, A.L., Birkeland, C.E. and Randall, R.H. (1999) Twenty years of disturbance and change in Fagatele Bay National Marine Sanctuary, American Samoa. Pacific Science 53, 376-400.

Guénette, S. and Pitcher, T.J. (1999) An age-structured model showing the benefits of marine reserves in controlling overexploitation. Fisheries Research 39, 295-303.

Halpern, B. (in press) The impact of marine reserves: do reserves work and does reserve size matter? Ecological Applications 83.

Hart, O., Shleifer, A. and Vishny, R.W. (1997) The proper scope of government - theory and an application to prisons. The Quarterly Journal of Economics 112, 1127-1161. 
Hellström, E. (2001) Conflict cultures - qualitative comparative analysis of environmental conflicts in forestry. Silva Fennica Monographs 2, 109 pp.

Hixon, M.A. and Carr, M.H. (1997) Synergistic predation, density-dependence, and population regulation in marine fish. Science $\mathbf{2 7 7}$, 946-949.

Hoffman, E., McCabe, K.A. and Smith, V.L. (1998) Behavioral foundations of reciprocity: experimental economics and evolutionary psychology. Economic Inquiry 36, 335-352.

Holland, K.N., Peterson, J.D., Lowe, C.G. and Wetherbee, B.M. (1993) Movements, distribution and growth rates of the white goatfish Mulloides flavolineatus in a fisheries conservation zone. Bulletin of Marine Science 52, 982-992.

Hubbard, R. (2000) Criteria of good governance. Optimum, The Journal of Public Sector Management 30, 37-50.

Jennings, S. (1998) Artisanal fisheries of the Great Astrolabe reef, Fiji - monitoring, assessment and management. Coral Reefs 17, 82 .

Jennings, S. (2001) Patterns and prediction of population recovery in marine reserves. Reviews in Fish Biology and Fisheries 10, 209-231.

Jennings, S. and Kaiser, M.J. (1998) The effects of fishing on marine ecosystems. Advances in Marine Biology 34, 201-352.

Jennings, S. and Polunin, N.V.C. (1996) Effects of fishing effort and catch rate upon the structure and biomass of Fijian reef fish communities. Journal of Applied Ecology 33, 400-412. 
Jennings, S. and Polunin, N.V.C. (1997) Impacts of predator depletion by fishing on the biomass an diversity of non-target reef fish communities. Coral Reefs 16, 71-82.

Johannes, R.E. (1980) Using knowledge of the reproductive behavior of reef and lagoon fishes to improve fishing yields. In: Fish Behavior and its use in the Capture and Culture of Fishes (eds J.E. Bardach, J.J. Magnuson, R.C. May and J.M. Reinhart), ICLARM Conference Proceedings 5, Manila, Philippines, pp. 247-270.

Johannes, R.E. (1998) The case for data-less marine resource management: examples from tropical nearshore finfisheries. Trends in Ecology and Evolution 13, 243-246.

Jones, G.P., Milicich, M.J., Emslie, M.J. and Lunow, C. (1999) Self-recruitment in a coral reef fish population. Nature 402, 802-804.

King, M. and Faasili, U. (1999) A network of small, community-owned Village Fish Reserves in Samoa. SPC Traditional Marine Resource Management and Knowledge Information Bulletin 11, 26.

Knack, S. and Keefer, P. (1997) Does social capital have an economic payoff? A cross-country investigation. Quarterly Journal of Economics 112, 1251-1288.

Kramer, D.L. and Chapman, M.R. (1999) Implications of fish home range size and relocation for marine reserve function. Environmental Biology of Fishes 55, 65-79.

Leis, J.M. and Carson-Ewart, B.M. (1998) Complex behaviour by coral-reef fish larvae in openwater and near-reef pelagic environments. Environmental Biology of Fishes 53, 259-266.

Lipcius, R.N., Stockhausen, W.T., Eggleston, D.B., Marshall Jr., L.S. and Hickey, B.M. (1997) Hydrodynamic decoupling of recruitment, habitat quality and adult abundance in the Caribbean 
spiny lobster: source-sink dynamics? Australian Journal of Marine and Freshwater Research 48, 807-815.

Lizaso, J.L.S., Goñi, R., Reñones, O. et al. (2000) Density dependence in marine protected populations: a review. Environmental Conservation 27, 144-158.

Lucas, J.S. (1994) The biology, exploitation, and mariculture of giant clams (Tridacnidae). Reviews in Fisheries Science 2, 181-223.

Man, A., Law, R. and Polunin, N.V.C. (1995) Role of marine reserves in recruitment to reef fisheries: a metapopulation model. Biological Conservation 71, 197-204.

Mascia, M.B. (2000) Institutional Emergence, Evolution, and Performance in Complex Resource Systems: Marine Protected Areas in the Wider Caribbean. Ph.D. dissertation, Department of the Environment, Duke University. 388 pp.

McCay, B.J. and Jentoft, S. (1998) Market or community failure? Critical perspectives on common property research. Human Organization 57, 21-29.

McClanahan, T.R. (1999) Is there a future for coral reef parks in poor tropical countries? Coral Reefs 18, 321-325.

McClanahan, T.R. and Mangi, S. (2000) Spillover of exploitable fishes from a marine park and its effect on the adjacent fishery. Ecological Applications 10, 1792-1805.

McManus, J.W., Meñez, L.A.B., Kesner-Reyes, K.N., Vergara, S.G. and Ablan, M.C. (2000) Coral reef fishing and coral-algal phase shifts: implications for global reef status. ICES Journal of Marine Science 57, 572-578. 
Milazzo, M. (1998) Subsidies in world fisheries: a reexamination. The International Bank for Reconstruction and Development, and The World Bank, Washington, D.C., 86 pp.

Milon, J.W. (2000) Pastures, fences, tragedies and marine reserves. Bulletin of Marine Science 66, 901-916.

Moberg, F. and Folke, C. (1999) Ecological goods and services of coral reef ecosystems. Ecological Economics 29, 215-233.

Mora, C. and Sale, P.F. (2002) Are populations of coral reef fish open or closed? Trends in Ecology and Evolution 17, 422-428.

Munro, J.L. (1996) The scope of tropical reef fisheries and their management. In Reef Fisheries (eds N.V.C. Polunin and C.M. Roberts). Chapman \& Hall, London, pp. 1-14.

Murray, S.N., Ambrose, R.F., Bohnsack, J.A. et al. (1999) No-take reserve networks: sustaining fishery populations and marine ecosystems. Fisheries 24(11), 11-25.

Narayan, D. and Pritchart, L. (1999) Cents and sociability: household income and social capital in rural Tanzania. Journal of Economic Development and Cultural Change 47, 871-897.

NRC (National Research Council) (1999) Sustaining Marine Fisheries. National Academy Press, Washington D.C. 184 pp.

North, D.C. (1990) Institutions, Institutional Change and Economic Performance. Cambridge University Press, Cambridge, U.K. 152 pp.

Olsen, M. (1965) The Logic of Collective Action: Public Goods and the Theory of Groups. Harvard University Press, Cambridge, Mass. 186 pp. 
Ostrom, E. (1990) Governing the Commons: The Evolution of Collective Action. Cambridge University Press, Cambridge, U.K. 280 pp.

Ostrom, E. (1998) A behavioural approach to the rational choice theory of collective action. American Political Science Review 92, 1-22.

Ostrom, E. (1999) Coping with Tragedies of the Commons. Annual Review of Political Science 2, 493-535.

Ostrom, E. (2000a) Private and common property rights. In: Encyclopedia of Law and Economics, Vol. 2 (eds B. Bouchaert and G. de Geest). Edward Elgar, Cheltenham, U.K., pp. 332-379.

Ostrom, E. (2000b) Social capital: a fad or a fundamental concept? In: Social Capital: A Multifaceted Perspective (eds P. Dasgupta and I. Serageldin), The World Bank, Washington, D.C., pp. $172-214$.

Ostrom, E., Gardner, R. and Walker, J. (1994). Rules, Games, and Common-Pool Resources. University of Michigan Press, Ann Arbor. 369 pp.

Paddack, M.J. and Estes, J.A. (2000) Kelp forest fish populations in marine reserves and adjacent exploited areas of central California. Ecological Applications. 10, 855-870.

Pauly, D., Christensen, V., Dalsgaard, J., Froese, R. and Torres Jr., F. (1998) Fishing down marine food webs. Science 279, 860-863.

Perrings, C. (1998) Resilience in the dynamics of economy-environment systems. Environmental and Resource Economics 11, 503-520. 
Picot, A. and Wolff, B. (1994) Institutional economics and public firms and administrations - some guidelines for efficiency-oriented design. Journal of Theoretical and Institutional Economics 150, 211-232.

Pitcher, T.J., Watson, R., Haggan, N. et al. (2000) Marine reserves and the restoration of fisheries and marine ecosystems in the South China Sea. Bulletin of Marine Science 66, 543-566.

Polunin, N.V.C. and Roberts, C.M. (1993) Greater biomass and value of target coral-reef fishes in two small Caribbean marine reserves. Marine Ecology - Progress Series 100, 167-176.

Pomeroy, R.S. (1995) Community-based and co-management institutions for sustainable coastal fisheries management in Southeast Asia. Ocean and Coastal Management 27, 143-162.

Ragin C.S. (2000) Fuzzy-set Social Science. University of Chicago Press, Chicago. 352 pp.

Roberts, C.M. (1997a) Ecological advice for the global fisheries crisis. Trends in Ecology and Evolution 12, 35-38.

Roberts, C.M. (1997b) Connectivity and management of Caribbean coral reefs. Science 278, 14541457.

Roberts, C.M. (2000) Selecting marine reserve locations: optimality versus opportunism. Bulletin of Marine Science 66, 581-592.

Roberts, C.M., Bohnsack, J.A., Gell, F., Hawkins, J.P. and Goodridge, R. (2001) Effects of marine reserves on adjacent fisheries. Science 294, 1920-1923.

Roberts, C.M. and Polunin, N.V.C. (1991) Are marine reserves effective in management of reef fisheries. Reviews in Fish Biology and Fisheries 1, 65-91. 
Roberts, C.M. and Polunin, N.V.C. (1993) Marine reserves: simple solutions to managing complex fisheries? Ambio 22, 363-368.

Rodwell, L.D. and Roberts, C.M. (2000) Economic implications of fully-protected marine reserves for coral reef fisheries. In: Collected Essays on the Economics of Coral Reefs (ed H.S.J. Cesar). CORDIO, Department of Biology and Environmental Sciences, Kalmar University, Sweden, pp 107-124.

Rudd, M.A. (2000) Live long and prosper: collective action, social capital and social vision. Ecological Economics 34, 131-144.

Rudd, M.A. (2001) The non-extractive economic value of spiny lobster, Panulirus argus, in the Turks and Caicos Islands. Environmental Conservation 38, 226-234.

Rudd, M.A. (in press) The effects of seafood import tariffs on market demand for Nassau grouper in the Turks and Caicos Islands. Proceedings of the Gulf Caribbean Fisheries Institute 54.

Rudd, M.A., Danylchuk, A.J., Gore, S.A. and Tupper, M.H. (2001) Are marine protected areas in the Turks and Caicos Islands ecologically or economically valuable? In: Proceedings of the International Conference on the Economics of Marine Protected Areas (eds J. Alder and U.R. Sumaila). UBC Fisheries Centre, Vancouver, pp. 198-211.

Rudd, M.A., Folmer, H. and van Kooten, G.C. (2002) Economic evaluation of recreational fishery policies. In: Evaluating Recreational Fisheries: an Ecological, Economic and Social Balance Sheet (eds T.J. Pitcher and C. Hollingworth). Blackwell Science, Oxford, pp. 35-52.

Rudd, M.A. and Tupper, M.H. (2002) The impact of Nassau grouper size and abundance on scuba diver site selection. Coastal Management 30, 133-151. 
Ruddle, K. (1995) A guide to the literature on traditional community-based fishery management in Fiji. SPC Traditional Marine Resource Management and Knowledge Information Bulletin 5, 7-15.

Ruddle, K. (1998) The context of policy design for existing community-based fisheries management systems in the Pacific Islands. Ocean and Coastal Management 40, 105-126.

Russ, G.R. and Alcala, A.C. (1996) Do marine reserves export adult fish biomass? Evidence from Apo Island, central Philippines. Marine Ecology Progress Series 132, 1-9.

Russ, G.R. and Alcala, A.C. (1998) Natural fishing experiments in marine reserves 1983-1993: community and trophic responses. Coral Reefs 17, 383-397.

Russ, G.R. and Alcala, A.C. (1999) Management histories of Sumilon and Apo Marine Reserves, Philippines, and their influence on national marine resource policy. Coral Reefs 18, 307-319.

Ruttan, L.M. (1998) Closing the commons - cooperation for gain or restraint. Human Ecology 26, 43-66.

Sammarco, P.W. and Andrews, J.C. (1998) Localized dispersal and recruitment in Great Barrier Reef corals: the Helix Experiment. Science 239, 1422-1424.

Sanchirico, J.N. and Wilen, J.E. ( 2001) A bioeconomic model of marine reserve creation. Journal of Environmental Economics and Management 42, 257-276.

Sladek Nowlis, J. and Roberts, C.M. (1999) Fisheries benefits and the optimum design of marine reserves. Fishery Bulletin 97, 604-616.

Smith, M.D. (2000) Spatial search and fishing location choice: methodological challenges of empirical modeling. American Journal of Agricultural Economics 82, 1198-1206. 
Stockhausen, W.T., Lipcius, R.N. and Hickey, B.M. (2000) Joint effects of larval dispersion, population regulation, marine reserve design, and exploitation on production and recruitment in the Caribbean spiny lobster. Bulletin of Marine Science 66, 957-990.

Sumaila, U.R., Guénette, S., Alder, J. and Chuenpagdee, R. (2000) Addressing ecosystem effects of fishing using marine protected areas. ICES Journal of Marine Science 57, 752-760.

Sutherland, A. (1986) Caye Caulker: Economic Success in a Belizean Fishing Village. Westview Press, Boulder, Colorado. 153 pp.

Tupper, M.H. and Boutilier, R.G. (1997) Effects of habitat on settlement, growth, predation risk and survival of a temperate reef fish. Marine Ecology Progress Series 151, 225-236.

Tupper, M.H. and Juanes, F. (1999) Effects of a marine reserve on recruitment of grunts (Pisces: Haemulidae) at Barbados, West Indies. Environmental Biology of Fishes 55, 53-63.

Tupper, M.H. and Rudd, M.A. (in press). Species-specific impacts of a small marine reserve on reef fish production and fishing productivity in the Turks and Caicos Islands. Environmental

\section{Conservation 29.}

Uphoff, N. and Wijayaratna, C.M. (2000) Demonstrated benefits from social capital: the productivity of farmer organizations in Gal Oya, Sri Lanka. World Development 28, 1875-1890.

van Kooten, G.C. and Bulte, E.H. (2000) The Economics of Nature. Blackwell Scientific, Oxford. $528 \mathrm{pp}$.

Veitayaki, J. (1998) Traditional and community-based marine resources management system in Fiji: an evolving integrated process. Coastal Management 26, 47-60. 
Virdin, J.W. (2000) An institutional model for comanagement of coastal resources in Fiji. Coastal Management 28, 325-335.

Walters, C. (1997) Challenges in adaptive management of riparian and coastal ecosystems. Conservation Ecology 1 (2):1 [online at www.consecol.org/vol1/iss2/art1].

Walters, C. (2000) Impacts of dispersal, ecological interactions, and fishing effort dynamics on efficacy of marine protected areas: how large should protected areas be? Bulletin of Marine Science 66, $745-757$.

Walters, C., Christensen, V. and Pauly, D. (1997) Structuring dynamic models of exploited ecosystems from trophic mass-balance assessments. Reviews in Fish Biology and Fisheries 7, 139172.

Watson, M. and Ormond, R.F.G. (1994) Effect of an artisanal fishery on the fish and urchin populations of a Kenyan coral reef. Marine Ecology Progress Series 109, 115-129.

White, A.T., Hale, L.Z., Renard, Y. and Cortesi, L. (1994) Collaborative and Community-Based Management of Coral Reefs: Lessons from Experience. Kumarian Press, West Hartford, Connecticut. $130 \mathrm{pp}$.

Wilen, J.E., Smith, M.D., Lockwood, D. and Botsford, L.W. (2002) Avoiding surprises: incorporating fisherman behavior into management models. Bulletin of Marine Science 70, 553575.

Williams, I.D. and Polunin, N.V.C. (2000) Differences between protected and unprotected reefs of the western Caribbean in attributes preferred by dive tourists. Environmental Conservation 27, 382391. 
Williamson, O.E. (1985) The Economic Institutions of Capitalism: Firms, Markets, Relational Contracting. The Free Press, New York. 450 pp.

Williamson, O.E. (1999) Public and private bureaucracies: a transaction cost economics perspective. Journal of Law, Economics and Organization 15, 306-341.

Woolcock, M. (1998) Social capital and economic development: toward a theoretical synthesis and policy framework. Theory and Society 27, 151-208.

Woolcock, M. (2001) The place of social capital in understanding social and economic outcomes. In: The Contribution of Human and Social Capital to Sustained Economic Growth and Well-Being: International Symposium Report (ed J.F. Helliwell). Human Resources Development Canada (HRDC) and Organisation for Economic Co-operation and Development (OECD), pp. 65-88.

Woolcock, M. and Narayan, D. (2000) Social capital: implications for development theory, research and policy. The World Bank Research Observer 15, 225-249.

World Bank (2000) Voices from the Village: A Comparative Study of Coastal Resource Management in the Pacific Islands. World Bank, Washington, D.C. 87 pp.

Young, H.P. (1996) The economics of convention. Journal of Economic Perspectives 10, 105-122.

Zann, L.P. (1999) A new (old) approach to inshore resources management in Samoa. Ocean and Coastal Management 42, 569-590.

Zeller, D.C. (1997) Home range and activity patterns of the coral trout Plectropomus leopardus (Serranidae). Marine Ecology Progress Series 154, 65-77. 


\section{List of Tables and Figures}

Table 1 - Types of economic values to consider in marine reserve analyses

Figure 1 - A classification of resources based on the ease of exclusion of non-authorized users and the degree of subtractability (after Ostrom et al. 1994) 
Table 1

Type of Economic Value

Example

Use Value

Extractive Direct Use

Fish captured for food

Non-Extractive Direct Use

Wildlife viewing by divers

Indirect Use

Maintenance of ecosystem resilience

Non-Use Value

Option Value

Value of conserving reefs for bioprospecting

Quasi-Option Value

Information for future fisheries managers

Bequest Value

Fishing lifestyle is available for children

Existence Value

Icon species preservation value to non-users 
Figure 1

Subtractability Low High

\begin{tabular}{|c|c|c|}
\hline$\stackrel{\Xi}{\Xi}$ Difficult & $\begin{array}{l}\text { Public } \\
\text { Goods }\end{array}$ & $\begin{array}{l}\text { Common } \\
\text { Pool } \\
\text { Resources }\end{array}$ \\
\hline Easy & $\begin{array}{c}\text { Toll } \\
\text { Goods }\end{array}$ & $\begin{array}{l}\text { Private } \\
\text { Goods }\end{array}$ \\
\hline
\end{tabular}

